\title{
PROPOSITION OF NEW METHODOLOGY FOR DEVELOPING BASIC TOPOGRAPHIC MAPS BASED ON REAL ESTATE CADASTRE DATABASE
}

\author{
Ilma Dinar, Slobodanka Ključanin, Vesna Poslončec-Petrić
}

Preliminary note

Production of civilian topographic maps is, traditionally, not common in Bosnia and Herzegovina. Such maps were produced by the Military Geographical Institute in Belgrade - military institution of Socialist Federal Republic of Yugoslavia (ex-YU). However, production of the so-called basic state maps was reserved for civil surveying (cartographic) institutes. Basic topographic maps (in Federation Bosnia and Herzegovina - FB\&H) have not been updated for more than 20 years. Due to that fact, it has been concluded that, instead of updating the existing maps, it is necessary to develop new metrology for creating topographic maps by using the available sources and new technologies. This paper provides a proposal for creating a new methodology for developing basic topographic maps at 1:5000 and 1:10000 scales. It is also necessary to emphasise that the Federal Administration for Geodetic and Property Affairs (FGA) initiated the creation of fundamental assumptions for contemporary development in the fields of cadastre and cartography. So, the FGA adopted the development strategies, cadastre and topographic models, established the real estate cadastre database and geoportals, etc.

Keywords: basic topographic map; real estate cadastre database; topographic data model

Prijedlog nove metodologije razvoja osnovne topografske karte temeljene na bazi podataka katastra nekretnina

Prethodno priopćenje Izrada civilnih topografskih karata tradicionalno nije bila u nadležnosti institucija u Bosni i Hercegovini. Takve karte izrađivane su u Vojno geografskom institutu u Beogradu - vojnoj instituciji Socijalističke Federativne Republike Jugoslavije. Međutim proizvodnja tzv. osnovnih državnih karata bila je u nadležnosti državnih geodetskih (kartografskih) instituta. Osnovne topografske karte (u Federaciji Bosne i Hercegovine - FBiH) nisu ažurirane više od 20 godina. Stoga je odlučeno da je umjesto ažuriranja postojećih karata, potrebno izraditi nove topografske karte uz pomoć dostupnih izvora i novih tehnologija. U radu se daje prijedlog za stvaranje nove metodologije izrade osnovne topografske karte u mjerilu 1: 5000 i 1: 10000 . Potrebno je naglasiti da je Federalna uprava za geodetske i imovinsko-pravne poslove Bosne i Hercegovine (FGU) inicirala stvaranje osnovnih pretpostavki suvremenog razvoja u području katastra i kartografije donošenjem strategije razvoja katastra i topografskih modela, modela podataka katastra nekretnina i distribucija podataka putem geoportala FGU itd.

Ključne riječi: baza podataka katastra nekretnina; osnovna topografska karta; topografski model podataka

\section{Introduction}

Topographic maps are used in many sciences, with special application in earth science, and serve as a reliable basis for spatial research and analysis. Traditional area of application for large scale topographic maps includes spatial and urban planning, i.e. general plans for municipality and settlements planning and development. Another area of application is technical projects in preimplementation stages $[1,2]$.

The division of topographic maps of Socialist Federal Republic of Yugoslavia (ex-Yugoslavia) was modelled on the division of USSR. Bosnia and Herzegovina inherited the division of topographic maps according to scale maps of ex-Yugoslavia, as follows: I - geodetic and cadastral maps (scale: 1: 500, 1: 1000, 1: 2500 1: 5000); II - basic (state) topographic maps (scale 1: 5000 and 1: 10 000); III - medium scale topographic maps (scale 1: 25000 to 1: 200000 ) and IV - general topographic maps (scale 1: 200000 to 1: 1000000 ).

Bosnia and Herzegovina did cultivate certain activities related to development of basic topographic maps; however, those activities have been stagnating for over 20 years. In those two decades, significant developments were achieved in technology and information science, which means that the process of developing such maps now requires an approach different from traditional. It is necessary to apply new and contemporary methods for developing topographic maps.

On the other hand, additional assumptions for initiating the development project of basic topographic maps have been created. Those assumptions involve adopting the topographic data model, populating the real estate cadastre database, existence of latest orthophoto digital plans, staff able to bring forth the project, funding and other conditions.

\section{Topographic data model}

Topographic data model represents the basis for developing a database management system. The model itself is an abstract, simplified representation of the observed real world, i.e. observed organizational system. Real-world elements are mapped in corresponding elements of the information system which represent segments of the real world in an abstract manner, suitable for computer processing $[3,4]$.

Topographic map contains the following themes:

- Relief (land shape)

- Water and buildings on water,

- Vegetation (land use),

- Inhabited settlements,

- Transport network,

- Boundaries,

- Names and descriptions, and

- Utility network.

One of the crucial conditions for initiating development of digital topographic maps is adopting the topographic data model (hereinafter: TDM) which defines the way in which real-world objects are represented and stored in the database. The catalogue of objects is created in accordance with international standard ISO 19110:2005 (Geographic Information - Methodology for Feature 
Cataloguing) and INSPIRE directives and is intended for topographic model and topographic data users.

Topographic data model contains the following class packages (Fig. 1):

- TIS_Building(TIS_Gradjevina)

- $\quad$ TIS_-TrafficNetwork(TIS_PrometnaMreza)
- TIS_Relief(TIS_Reljef)

- TIS_Toponym(TIS_Toponim)

- $\quad$ TIS - LandCover(TIS PokrovZemljista)

- TIS_Hydrography(TIS_Hidrografija)

- TIS_UtilityNetwork(TIS_Vod)[5].

\begin{tabular}{|c|c|c|c|}
\hline \multicolumn{4}{|c|}{ ObradivoZemljisteTip (CultivatedLandType) } \\
\hline Oznaka & \multirow{3}{*}{ Klasa: } & \multirow{3}{*}{ ObradivoZemljiste (CultivatedLand) } & \\
\hline Oranica & & & \\
\hline \multirow{2}{*}{$\begin{array}{l}\text { Rasadnik } \\
\text { Hmeljište } \\
\end{array}$} & & & \\
\hline & \multirow{8}{*}{\begin{tabular}{|l|} 
Stereotip: \\
\end{tabular}} & $\begin{array}{l}\text { inspireId : INSPIRE Base Types::Identifier } \\
\text { jedinstveni INSPIRE identifikator topografskog objekta }\end{array}$ & $\mathbf{0}$ \\
\hline Vit & & $\begin{array}{l}\text { naziv : GeographicalNames: GeographicalName } \\
\text { naziv obradivog zemljista }\end{array}$ & $\mathbf{n}$ \\
\hline $\begin{array}{l}\text { Staklenik } \\
\text { Plastenik } \\
\end{array}$ & & $\begin{array}{l}\text { kultura : ObradivoZemljisteTip } \\
\text { tip/vrsta obradivog zemljišta }\end{array}$ & o \\
\hline $\begin{array}{ll}\text { Voćnjak } \\
\text { Maslenik }\end{array}$ & & $\begin{array}{l}\text { transactionTime : TM_Period } \\
\text { vremenski period (interval trajanja) objekta unutar sustava }\end{array}$ & o \\
\hline Vinograd & & $\begin{array}{l}\text { validTime : TM_Period } \\
\text { vremenski period (interval trajanja) objekta u stvarnom svijetu }\end{array}$ & $\mathbf{0}$ \\
\hline \multirow[t]{4}{*}{ Livada } & & napomena : CharacterString & $\mathbf{n}$ \\
\hline & & izvorGeometrije : IzvorGeometrijeTip & o \\
\hline & & geometrija : GM_Surface & $\mathbf{0}$ \\
\hline & Napomena: & & \\
\hline
\end{tabular}

Figure 1 Representation of "CultivatedLand" class in TDM and list of values for its "Typ" attribute

\section{Datasets used for developing basic topographic maps}

Development of any product, including the topographic maps, has, as its aim, the utmost quality of the product in question. We can state that quality of new maps depends on selection of adequate and reliable sources $[6,7]$. Therefore, it is very important that the cartographer is in possession of multiple datasets which complement one another so selection of objects to be shown on the map makes the map up-to-date and aesthetically appealing. Other important notions that should be taken into account are accuracy, creation date, purpose and origin of used data.

In this example, a map of the municipality of Neum was made in scale 1: 5000 and 1:10 000. Neum is a town which lies in the far south of Bosnia and Herzegovina. Located in the tourist region of the southern Adriatic, it is the only Adriatic Sea coastline that B\&H has.

Since basic topographic maps always use sets of cartographic data collected for larger scale topographic plans (digital data for topographic plans visualisation) the following vector datasets have been collected for spatial coverage of Municipality of Neum (which contains three cadastral communities):

a) Real estate cadastre datasets,

b) Information and data from analogue topographic plans at 1:500, 1:1000 and 1:2500 scales,

c) digital orthophoto plans,

d) digital terrain model and

e) Information about topographic data model.

Listed data (and information) were taken from the FGU in different formats (GML, tiff, UMG and other). FGU geoportal also provided data of main roads as well as of hydrographic network. Appropriate entities' organizations and agencies guarantee for data accuracy.

\subsection{Real estate cadastre database}

Real estate cadastre database was created based on the Real Estate Cadastre Data Model [8]. Data required for the real estate cadastre database were acquired by vectorization of cadastre plans (without terrain elevation data), as well as regular cadastre maintenance - geodetic surveying, i.e. recording the changes (geometric and thematic) that occurred over time.

Content of the database is classified (in accordance with the Regulations on real estate cadastre data) into two groups - basic and extended content. Basic content involves:

- Geodetic base survey,

- Cadastral parcels,

- Parts of cadastral parcels based on the land use,

- Buildings and other constructions,

- Boundaries of administrative and cadastral territorial units,

- Textual descriptions and names,

- Other data.

- Extended content involves:

- Boundaries of administrative and territorial units for statistics,

- Infrastructure construction objects,

- Traffic roads,

- Water and buildings on water,

- Relief and topography,

- Other objects.

Regulations on real estate cadastre data stipulate data accuracy [9]. Listed content of the real estate cadastre database was acquired for the Municipality of Neum.

\subsection{Analogue plans}

Vector data stored in the real estate cadaster database are obtained by digitalizing analog plans. This process includes primarily scanning the analog plans using the 
digitizer with the accuracy of $0,125 \mathrm{~mm}$ or better [10] and then georeferencing i.e. joining geographic data to the already known coordinate system [11] during which we use all available points of the grid analogue plan. After georeferencing, the next step is manual vectorization of the content of the cadastral plan in accordance with the Model of real estate cadastre data [8].

The used analogue plans (Fig. 2) were acquired in tiff format and have already been georeferenced. Those plans were used for amending the content in case where toponyms for specific objects are missing, resolving dilemmas about vegetation display (i.e. land use) and determinate object types in certain classes (e.g. religious buildings).

Analogue plans that were used as the source, completely covering the territory of cadastral communities of Gradac, Moševići and Neum were created at different scales. Inhabited areas in the coastal zone are mapped at a larger scale (1:500) while other areas are mapped at 1:1000 and 1:2500, depending on detail density.

Analogue plans were created in 1974 and updated in 1985 , based on aerial photographic surveying. The update process required classical geodetic land surveying of objects on the ground. Figure 2 shows objects mapped in red - those objects underwent changes of shape, surface (size), or purpose.

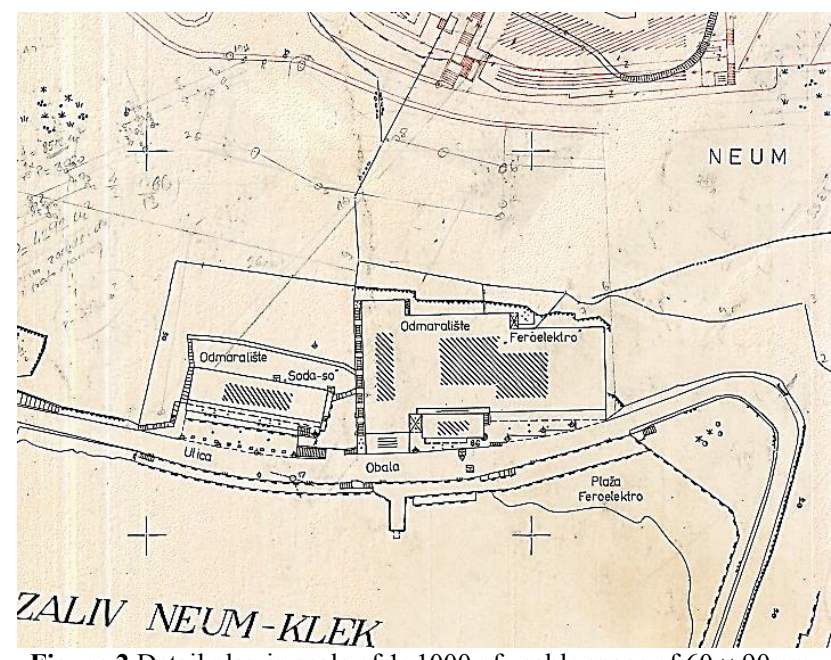

Figure 2 Detail plan in scale of 1: 1000 of usable space of $60 \times 90 \mathrm{~cm}$. The plan is based on the survey by the Geodetic Institute of Sarajevo in 1977, and certified by the Geodetic Administration of the Republic of Bosnia and Herzegovina. Data of the survey are outlined in black, while the red details were drawn while maintening plans.

\subsection{Digital orthophoto plan}

Until now, two projects related to creating digital orthophoto plans were conducted in FB\&H (in 2008 and in 2014). However, more recent digital orthophoto plans were used for the purpose of creating basic topographic maps.

The 2008 IPA project involved recording the entire territory of Bosnia and Herzegovina. Recording resolution was $40 \mathrm{~cm}$, and the recording resulted in 12603 images that were used for creating a digital orthophoto of the entire country. The orthophoto plan accuracy and resolution correspond to scale 1:5000. Another 8768 images were made, with resolution of $25 \mathrm{~cm}$, and those were used for creating a digital orthophoto plan of urban $\mathrm{B} \& \mathrm{H}$ areas [12].

\subsection{Digital terrain model}

Considering the fact that cadastral plans do not include terrain elevation data (such data are not included in the real estate cadastre database either) it is necessary to use a digital terrain model in order to create desired topographic map (i.e. object class TIS_Relief). Digital terrain model created in 2008 was selected for use, its grid cell size was $5 \mathrm{~m} \times 5 \mathrm{~m}$ and it was created as a result of autocorrelation process with data collected by taking photographs during flights. Digital terrain model was later improved and enhanced for rural areas.

\subsection{Data for main traffic roads and hydrographic network}

Data for main traffic roads and hydrographic network were acquired from FGU geoportal. After acquiring and inspecting the data it was noticed that data accuracy is significantly lower than that required for developing basic topographic maps. Therefore, those data were not used in this project. Instead, the data have been vectored from corresponding topographic maps and digital orthophoto plans.

\section{Data processing}

After collecting different sets of spatial data and after inspecting the data by date of origin, geometric and thematic accuracy, format in which they are stored, it was necessary to select a tool that would enable highest utilization of collected data. Nonetheless, there is always the need to editing the existing data. Therefore, developing the topographic maps required data reprocessing and update (digitalization of analogue maps, thematic data entry, object groups creation, etc.).

Basic vector dataset used for developing the topographic maps was acquired from real estate cadastre database. In other words, topographic maps development requires acquiring datasets from real estate cadastre database, their transformation depending on the topographic data model and their update with data from other sources.

\subsection{Real estate cadastre data selection and transformation in accordance with regulations}

Spatial data that is used to produce cadastral maps (topographic maps of the largest scale) should also be used for the production of basic topographic maps. This reduces duplication of data, saves time collecting and processing the new data, and the data used are the same accuracy or higher than required for the production of basic topographic maps.

Since real estate cadastre database was created for the purpose of recording data and visualisation of cadastre parcels and other related objects it contains more data than the topographic model requires. In addition to that, objects nomenclature and identification numbers are different. On the other hand, topographic model for certain object types requires defining different geometry 
than that in the real estate cadastre database. Therefore, it is necessary to perform adequate data selection from the database, inspect their geometry and other mandatory attributes stipulated by the topographic model and perform adequate data transformation (if necessary).



Figure 3 Locating matching classes in both models

For example, object KAT_Building (from real estate cadastre database) whose attribute "Type" is 510 (code for residential buildings) matches class "ResidentialObject" from class package "TIS Building" in topographic data model (Fig. 3). Therefore, theme "Building" from real estate cadastre database contains the same objects as theme (class package) TIS_Building from topographic data model.

Detailed review of content comparison between real estate cadastre database, topographic data model and the possibility to select corresponding data was performed and the following was reached as a conclusion:

- Real estate cadastre database contains data for buildings with the following labels: "Auxiliary", "Auxiliary in the economy", and "Auxiliary in the outside economy ". Those buildings were not present in topographic data model. Considering that, it is proposed that new class should be defined in the topographic data model and its name set to "AuxiliaryBuilding".

- According to the TDM, class package TIS TrafficNetwork is acquired from INSPIRE directive specifications. Very little information is taken from the real estate cadastre database. Data for this class are mostly vectored from digital orthophoto plans. Road class does not imply roads classification into multiple types; however, that is crucial if we want the topographic map to resemble the traditional appearance the users appreciate. Therefore, classes Road Highway, Road State_Road, Road_Local_road, Road Dirt road and Road Trail have been included within this class package even though they were not stipulated in the topographic data model.

- Digital terrain model was used for class package TIS Relief which was also acquired from INSPIRE directive specifications. It contains multiple classes, those used for the topographic maps are ContourLine and SpotElevation. Contour lines of rather small range were replaced by point marks associated with height (elevation) information which are found in SpotElevation class.

- Class package TIS Toponym has only "Toponym" class which contains names of different types of geographical units and objects. Because of simpler visualization, the "Toponym" class can be complemented with the following classes:

- Administrative unit,

- Building,

- Hydrography,

- Land use,

- Land shape,

- Inhabited settlement,

- Protected place/area,

- Transport network,

- Utility network.

According to the topographic data model, data from this class package are, geographically, represented as points. The visualization would include showing names on those point positions. However, it appears to be more practical that the data related to database toponyms are joined to a linear or polygon object, depending on objects themselves. An advantage of that method is the fact it allows data to be visualized in different scales and it also allows selection of toponyms to be shown depending on line length or polygon size.

- In the project of creating the topographic maps the toponym classes are created with reference to analogue plans. LandUse class was created by grouping parcels with the same purpose and name from the real estate cadastre database. Considering the fact that a great number of toponyms with the same name were created, it was necessary to join another attribute to the class - attribute related to named area surface/size. That attribute was used for eliminating duplicate names by deleting names related to a smaller surface. In addition to that, that attribute was used for joining another condition to the visualization - the condition of showing names of areas whose surface is larger than the set value.

- TIS LandCover specifies the land use purpose. This class package contains multiple classes - each class from topographic data model has a corresponding class in the real estate cadastre database. Lands from the real estate cadastre database whose purpose was labelled as "Land under the building" are, according to the regulations for topographic data model classified as lands surrounded by lands with buildings since another corresponding class does not exist.

- Class package TIS_Hydrography was created based on data from the real estate cadastre database and data acquired through analogue plans digitalization. According to the real estate cadastre database, certain lands hydrography was labelled as "Stream" (code $\mathrm{P} 0605016$ ) and is related to the area that surrounds that water flow. Therefore it was recommended to add class "Trough".

- Data for class package TIS_UtilityNetwork were mainly acquired through analogue plans digitalization. Only specific classes (ObjectOilLine, ObjectGasLine, 
HeatingSystem, WaterSupply) can be created by using data from the real estate cadastre database.

\subsection{Topology control}

After data entry into the topographic database but before the visualization process it is necessary to inspect the topology. Topology is a branch of mathematics concerned with generalization of the concept of continuity, limit, etc. [13]. Topology of spatial objects represents a set of geometric relations between links, nodes, and centroids; it defines the methods that vector data organized which allows analysis and description of objects independent of their geometric properties. The existence of topology is a prerequisite for performing various spatial analyses. Within the topology, objects are joined with certain features:

- Divisibility - spatial objects (e.g. lines) belong to a greater number of higher level objects (one line can be a boundary for a parcel, a cadastral community, canton or even a state).

- Connection - objects can join and build on each other,

- Neighbourhood (continuity) [14].

In GIS, topology is implemented through data structure. The structure of the data model describes the elements, entities, attributes, relations, etc., which are selected from the system to be analysed and which form a data model. Finding and correcting topology errors is considered to be the implementation of operations on data. The procedure of inspecting the topology in GIS software includes selection of first and second layer and defining the relation between the two. The relation between the layers is represented by using the topological rules, e.g. the overlapping rule.

It is necessary to ensure that same-type objects do not overlap in any of the class packages. For example, class package related to land cover area does not contain overlapping between polygons (land use), and class package TIS_Building does not contain overlapping between polygons that represent man-made objects.

Each class package needs to conform to additional regulations due to specific objects from certain layers. Following that, the class package related to hydrography implies that areas covered with lakes, seas and other water flows cannot be overlapped and that watercourse lines can touch at the ends only. Therefore, layer related to transport network needs to ensure there is no overlap between roads and railways, or same-type objects (points of intersection need to be represented with nodes, i.e. level crossing).

\section{Conclusion}

The project of developing basic topographic maps for Municipality Neum included detailed analysis of relations between two existing models - real estate cadastre and topographic data model.

Since the two represent different approaches to topographic-cadastral plans and topographic maps development this project noted expected inconsistencies between the real estate cadastre database and topographic data model. It is necessary to take into consideration the fact that the topographic model was created in accordance with international rules and regulations while practice shows that traditional approach is still rather common.

After data entry into the topographic database it was concluded that it is necessary to use at least four sources (used for this project) and that value of certain attributes cannot be determined before field inspections. It was also concluded that the topographic model needs to be expanded for certain classes/class packages (e.g. administrative boundaries etc.).

For the formation of adequate registries and regulations necessary for active implementation of the TDM it is necessary to create a legislative framework, provide trained staff, time and funding. In addition to numerous recommendations for TDM improvements, the results of the project confirmed that it is necessary to use new methodology for developing basic topographic maps and other cartographic products created through topographic database.

\section{References}

[1] Lovrić, P. Opća kartografija, Sveučilišna naklada Liber, Zagreb, 1988.

[2] Poslončec-Petrić, V. Distribution of Spatial Data official cartography in the Republic of Croatia, PhD. thesis, University of Zagreb - Faculty of Geodesy, Zagreb, 2010.

[3] Osmanović, K. Formiranje kartografske baze podataka u GeoMedia/Oracle Spatial okolišu. Graduate Thesis, University of Sarajevo - Faculty of Civil Engineering Department of Geodesy, Sarajevo, 2005.

[4] Borisov, M. Problems of the Scale and Building of Topographical Data Infrastructure. // Geodetski list, Zagreb, Croatia. 2(2010), pp. 109-116.

[5] Federal Administration for Geodetic and Property Affairs, Topografski model podataka - Katalog objekata, URL: http://www.fgu.com.ba/hr/model-podataka.html, (06.03.2015)

[6] Poslončec-Petrić, V.; Birin, I. Kartografski izvornici i mogućnosti njihova korištenja. // Ekscentar, Zagreb. 8, (2006), pp. 38-42.

[7] Poslončec-Petrić, V.; Birin, I.; Frangeš, S. Evidencije prostornih podataka u autorskoj kartografiji. // Geodetski list, Zagreb. 67, 90(2013), pp. 29-40.

[8] Federal Administration for Geodetic and Property Affairs, Model podataka katastra nekretnina - Katalog objekata, URL: $\quad \mathrm{http}: / /$ www.fgu.com.ba/hr/model-podataka.html, (06.03.2015)

[9] Geofoto, BiH DOF - Izrada digitalnog ortofota Bosne i Hercegovine, URL: http://www.geofoto.hr/index.php/hr /vijesti/322-bih-dof.html, (01.03.2015)

[10] Federalna uprava za geodetske i imovinsko - pravne poslove, Pravilnik o bazi podataka katastra nekretnina, Sarajevo, 2008. http://www.fgu.com.ba/bs/pravilnici.html, (17.05.2015)

[11] ESRI, GIS Dictionary, http://support.esri.com/en/ knowledgebase/GISDictionary/term/georeferencing, (17.05.2015)

[12] Zdjelar, D. Prilog istraživanju izrade i primjene krupnorazmjernih karata sa aspekta stanja i razvoja kartografije u Bosni i Hercegovini. // Doctoral Dissertation, Universityof Sarajevo - Faculty of Civil Engineering Department of Geodesy, Sarajevo, 1992.

[13] TheFreeDictionary.com, http://www.thefreedictionary.com/ topology, (17.05.2015) 
[14] Mačak N. Model podataka katastra nekretnina Bosne i Hercegovine. // Graduate Thesis, University of Zagreb Faculty of Geodesy, Zagreb, 2002.

\section{Authors' addresses}

Ilma Dinar, MA Geodesy

Breza Municipality Cadastre,

Bogumilska 1, 71370 Breza, Bosnia and Herzegovina

E-mail: ilma_dinar@hotmail.com

\section{Slobodanka Ključanin, PhD.}

Universityof Sarajevo,

Faculty of Civil Engineering Department of Geodesy,

Patriotskelige 30, 71000 Sarajevo, Bosnia and Herzegovina

E-mail: slobodanka63@yahoo.com

\section{Vesna Poslončec-Petrić, PhD}

University of Zagreb, Faculty of Geodesy

Andrije Kačića Miošića 26; 10000 Zagreb, Croatia

E-mail: vesna.posloncec@geof.hr 